\title{
Chemotherapy Response Score 1
}

National Cancer Institute

\section{Source}

National Cancer Institute. Chemotherapy Response Score 1. NCI Thesaurus. Code C159368.

No or minimal tumor response. 